\title{
Prevalence of obesity among school children aged 6-18 years with special reference to differences in government and private schools
}

\author{
Gandhi ${ }^{1}$, Phuljhele $S^{2}$, Rao B.N $\mathbf{N}^{3}$ \\ ${ }^{1}$ Dr Animesh Gandhi, M.D Student, ${ }^{2}$ Dr. Sharja Phuljhele, Professor and Head, ${ }^{3}$ Dr. Badri Narayan Rao, Associate \\ Professor; all authors are affiliated with Department of Paediatrics, Pt. JNMMC and Dr BRAMH Raipur, C.G, India
}

Address for Correspondence: Dr Animesh Gandhi, Department of Pediatrics, JNMC, Raipur, Email id: animeshgandhi4@gmail.com

\begin{abstract}
Introduction: In the society which is switching towards Non communicable diseases, lack of physical activity and luxurious lifestyle and long sitting area in schools have contributing a lot to emerging obesity in school age group students. Overweight and obesity in childhood continues in adulthood and increases the burden of cardiovascular disease. Aims: is to study the prevalence of obesity among school children aged 6-18 years in government and private schools in Raipur City of Chhattisgarh with Objectives being to evaluate association of some modifiable risk factors. Material and Methods: A cross sectional study conducted in urban schools of Raipur from March15 to April-16. Equal number of government (15) and private schools (15) were selected by cluster sampling method and all children of 6 to 18 years age group were studied. Sample size was calculated using formula $4 \mathrm{pq} / \mathrm{l}^{2}$ which was 1640 . Materials like were weighing machine, measuring tape, portable stadiometer and BMI percentile curves were used. The prevalence of obesity was calculated and associations between modifiable factors were established using Spearman's chi square test. ( $p<0.05)$. Data was analyzed using SSPS (version 16.0). Results: Prevalence of obesity is $13.46 \%$ among 6-18 in Raipur city and Prevalence of overweight is $\mathbf{1 0 . 5 4 \%}$ and factors that are significantly associated with obesity are less duration of physical activity, studying in private school, Increased intake of chocolates/drinks and fast food, going school in vehicles, female gender and small playground area in school. Conclusion: overweight and obesity are continuously expanding in our city, proper physical activity routine and dietary habits should be set intricately as best as possible.
\end{abstract}

Key words: Overweight, obesity, BMI, Physical activity, Dietary habit

\section{Introduction}

Obesity is defined as a situation by which there is excess body fat leading to health impairment [1,2]. Obesity is defined using age and sex specific normograms for BMI [3]. Obesity in itself contributes to 2.6 million deaths worldwide every year and has become a colossal epidemic [5]. Obesity is an independent risk factor for CVD and is associated with an increased risk of morbidity and reduced life expectancy. Obesity has reached epidemic proportions globally [1]. The rising prevalence of obesity in developing countries is largely due to reduction in the energy expenditure which has resulted from rapid urbanization and mechanization, increase in energy

Manuscript received: $4^{\text {th }}$ May 2017

Reviewed: $14^{\text {th }}$ May 2017

Author Corrected: $23^{\text {rd }}$ May 2017

Accepted for Publication: $31^{\text {st }}$ May 2017 intake due to increased purchasing power and availability of high fat/energy-dense fast food [4]. The reasons for obesity during childhood depends on consuming junk food, social factors, life style of family life, television / computers, lack of activity and inadequate play areas [5]. School based data on obesity in India shows a prevalence of 5.6 - 24\% among children and adolescent. The large range in the reported prevalence of overweight and obesity could be due to regional differences and non-uniformity in the criteria used to classify socio economic status.

Obesity is associated with increased risk of the metabolic syndrome, type 2 diabetes mellitus (T2DM), hypertension, dyslipidaemia, polycystic ovarian syndrome (PCOS) and coronary heart disease (CHD). 
In fact some of these metabolic derangements start in childhood [6].

\section{Aim and objectives of the study}

1. To study the prevalence of obesity among school children aged 6-18 years in government and private schools in Raipur City of Chhattisgarh.

2. Identifying, evaluating, analyzing and establishing some association among modifiable factors (physical activity, feeding habits, environmental factors, family \& school) and obesity in school children.

3. To identify any variation as per age, gender, and type of school (government and private).

\section{Materials and Methods}

Study design: Cross sectional observational.

Study setting: This was a cross sectional study conducted in urban schools of Raipur City from March 15 to April-16 after obtaining ethics committee approval.

Inclusion criteria: All the children present in selected schools from age 6 to 18 years.

Exclusion criteria: 1. Age <6yrs and >18yrs. 2 . Children not willing to participate. 3. Those with $\mathrm{Ht} / \mathrm{Wt}$ error during data management. 4. Physically challenged children. 5. Children on drugs like steroids. 6. Children diagnosed to be suffering from metabolic or endocrinal disorder causing obesity.
Participants: Equal number of government (15) and private schools (15) were selected by cluster sampling method and children were included from the age group of 6 to 18 years studying in these schools who fulfilled the inclusion criteria.

Variables: Weight, Height, BMI, Waist circumference, Hip circumference.

Data source: list of all schools in Raipur city was obtained from state education board. Sample size was calculated using formula which was 1640 .

Materials used in study were weighing machine (digital with $0.5 \mathrm{~kg}$ error), measuring tape (non stretchable), portable stadiometer and BMI percentile curves.

Statistical method: The prevalence of obesity was calculated and association between modifiable factors was established using Spearman's chi square test. $(\mathrm{p}<0.05)$. Data was analyzed using SSPS [Statistical package for the Social Sciences] (version 16.0).

Atlanta Odds ratio (OR) and Confidence Interval (CI) calculator was used to calculate Odds ratio and 95\% confidence interval. Children were categorized into three groups by using age- and sex-specific percentiles of BMI.

a) Obese ( $>95^{\text {th }}$ percentile),

b) Overweight $\left(\geq 85^{\text {th }}\right.$ percentile) and

c) Normal $\left(5^{\text {th }}\right.$ to $<85^{\text {th }}$ percentile $)$

\section{Results}

Table-1

\begin{tabular}{|c|c|c|c|c|c|}
\hline Age (Years) & Male & Percentage & Female & Percentage & Total \\
\hline $5-10$ & 396 & 21.41 & 405 & 21.89 & 801 \\
\hline $11-15$ & 455 & 24.59 & 192 & 10.38 & 647 \\
\hline $16-18$ & 238 & 12.86 & 164 & 8.86 & 402 \\
\hline Total & 1089 & 58.86 & 761 & 41.14 & 1850 \\
\hline
\end{tabular}

Table 1 Showing male \&, female distribution and total number of students included in the study, which are divided into three age bands i.e 5-10,11-15 and 16-18years. Maximum number of students were from $1^{\text {st }}$ age band. Males are more in $2^{\text {nd }}$ band and females are more in $1^{\text {st }}$ band. 
Table-2: Distribution of students according to BMI categories.

\begin{tabular}{|c|c|c|}
\hline BMI category & No. of subjects & Percentage \\
\hline Underweight & 84 & 4.54 \\
\hline Normal & 1322 & 71.46 \\
\hline Overweight & 195 & 10.54 \\
\hline Obese & 249 & 13.46 \\
\hline Total & 1850 & 100 \\
\hline
\end{tabular}

Table 2 shows BMI categories of complete sample size. Out of 1850 students $249(13.46 \%)$ were found to be obese and $195(10.54 \%)$ were overweight.

Table-3: Age-wise distribution of BMI Categories (Girls).

\begin{tabular}{|c|c|c|c|c|c|c|c|}
\hline & & & \multicolumn{4}{|c|}{ BMI Category } & \multirow[t]{2}{*}{ Total } \\
\hline & & & Underweight & Normal & Overweight & Obese & \\
\hline \multirow{28}{*}{$\begin{array}{c}\text { Age } \\
\text { (Years) }\end{array}$} & \multirow[t]{2}{*}{6} & Count & 14 & 109 & 7 & 13 & 143 \\
\hline & & \% within Age (Years) & $9.8 \%$ & $76.2 \%$ & $4.9 \%$ & $9.1 \%$ & $100.0 \%$ \\
\hline & \multirow[t]{2}{*}{6.5} & Count & 2 & 1 & 0 & 0 & 3 \\
\hline & & $\%$ within Age (Years) & $66.7 \%$ & $33.3 \%$ & $.0 \%$ & $.0 \%$ & $100.0 \%$ \\
\hline & \multirow[t]{2}{*}{7} & Count & 9 & 45 & 7 & 19 & 80 \\
\hline & & $\%$ within Age (Years) & $11.2 \%$ & $56.2 \%$ & $8.8 \%$ & $23.8 \%$ & $100.0 \%$ \\
\hline & \multirow[t]{2}{*}{8} & Count & 4 & 22 & 1 & 6 & 33 \\
\hline & & $\%$ within Age (Years) & $12.1 \%$ & $66.7 \%$ & $3.0 \%$ & $18.2 \%$ & $100.0 \%$ \\
\hline & \multirow[t]{2}{*}{9} & Count & 1 & 44 & 0 & 9 & 54 \\
\hline & & $\%$ within Age (Years) & $1.9 \%$ & $81.5 \%$ & $.0 \%$ & $16.7 \%$ & $100.0 \%$ \\
\hline & \multirow[t]{2}{*}{10} & Count & 6 & 34 & 12 & 40 & 92 \\
\hline & & $\%$ within Age (Years) & $6.5 \%$ & $37.0 \%$ & $13.0 \%$ & $43.5 \%$ & $100.0 \%$ \\
\hline & \multirow[t]{2}{*}{11} & Count & 2 & 19 & 6 & 2 & 29 \\
\hline & & $\%$ within Age (Years) & $6.9 \%$ & $65.5 \%$ & $20.7 \%$ & $6.9 \%$ & $100.0 \%$ \\
\hline & \multirow[t]{2}{*}{12} & Count & 1 & 25 & 8 & 29 & 63 \\
\hline & & $\%$ within Age (Years) & $1.6 \%$ & $39.7 \%$ & $12.7 \%$ & $46.0 \%$ & $100.0 \%$ \\
\hline & \multirow[t]{2}{*}{13} & Count & 1 & 54 & 9 & 7 & 71 \\
\hline & & $\%$ within Age (Years) & $1.4 \%$ & $76.1 \%$ & $12.7 \%$ & $9.9 \%$ & $100.0 \%$ \\
\hline & \multirow[t]{2}{*}{14} & Count & 1 & 27 & 6 & 7 & 41 \\
\hline & & $\%$ within Age (Years) & $2.4 \%$ & $65.9 \%$ & $14.6 \%$ & $17.1 \%$ & $100.0 \%$ \\
\hline & \multirow[t]{2}{*}{15} & Count & 1 & 82 & 2 & 3 & 88 \\
\hline & & $\%$ within Age (Years) & $1.1 \%$ & $93.2 \%$ & $2.3 \%$ & $3.4 \%$ & $100.0 \%$ \\
\hline & \multirow[t]{2}{*}{16} & Count & 2 & 62 & 0 & 0 & 64 \\
\hline & & \% within Age (Years) & $3.1 \%$ & $96.9 \%$ & $.0 \%$ & $.0 \%$ & $100.0 \%$ \\
\hline & \multirow[t]{2}{*}{17} & Count & 2 & 47 & 11 & 4 & 64 \\
\hline & & $\%$ within Age (Years) & $3.1 \%$ & $73.4 \%$ & $17.2 \%$ & $6.2 \%$ & $100.0 \%$ \\
\hline & \multirow[t]{2}{*}{18} & Count & 0 & 24 & 5 & 7 & 36 \\
\hline & & $\%$ within Age (Years) & $.0 \%$ & $66.7 \%$ & $13.9 \%$ & $19.4 \%$ & $100.0 \%$ \\
\hline \multirow{2}{*}{\multicolumn{2}{|c|}{ Total }} & Count & 46 & 595 & 74 & 146 & 860 \\
\hline & & $\%$ within Age (Years) & $5.3 \%$ & $69.1 \%$ & $8.6 \%$ & $17.0 \%$ & $100.0 \%$ \\
\hline
\end{tabular}

Table 3 shows age wise distribution of BMI categories in Girls. Girls of age 12 yrs have maximum proportion of obese population and girls of age 16 year had minimum proportion of obesity. 
Table 4: Age-wise distribution of BMI Categories (Boys).

\begin{tabular}{|c|c|c|c|c|c|c|c|}
\hline & & & \multicolumn{4}{|c|}{ BMI Category } & \multirow[t]{2}{*}{ Total } \\
\hline & & & Underweight & Normal & Overweight & Obese & \\
\hline \multirow{32}{*}{$\begin{array}{c}\text { Age } \\
\text { (Years) }\end{array}$} & \multirow[t]{2}{*}{5} & Count & 0 & 1 & 0 & 0 & 1 \\
\hline & & $\%$ within Age(Yrs) & $.0 \%$ & $100.0 \%$ & $.0 \%$ & $.0 \%$ & $100.0 \%$ \\
\hline & \multirow[t]{2}{*}{6} & Count & 16 & 106 & 7 & 11 & 140 \\
\hline & & $\%$ within Age & $11.4 \%$ & $75.7 \%$ & $5.0 \%$ & $7.9 \%$ & $100.0 \%$ \\
\hline & \multirow[t]{2}{*}{6.5} & Count & 0 & 2 & 0 & 0 & 2 \\
\hline & & $\%$ within Age & $.0 \%$ & $100.0 \%$ & $.0 \%$ & $.0 \%$ & $100.0 \%$ \\
\hline & \multirow[t]{2}{*}{7} & Count & 10 & 51 & 7 & 22 & 90 \\
\hline & & $\%$ within Age & $11.1 \%$ & $56.7 \%$ & $7.8 \%$ & $24.4 \%$ & $100.0 \%$ \\
\hline & \multirow[t]{2}{*}{7.5} & Count & 0 & 2 & 0 & 0 & 2 \\
\hline & & $\%$ within Age & $.0 \%$ & $100.0 \%$ & $.0 \%$ & $.0 \%$ & $100.0 \%$ \\
\hline & \multirow[t]{2}{*}{8} & Count & 4 & 56 & 4 & 5 & 69 \\
\hline & & $\%$ within Age & $5.8 \%$ & $81.2 \%$ & $5.8 \%$ & $7.2 \%$ & $100.0 \%$ \\
\hline & \multirow[t]{2}{*}{9} & Count & 0 & 34 & 2 & 1 & 37 \\
\hline & & $\%$ within Age & $.0 \%$ & $91.9 \%$ & $5.4 \%$ & $2.7 \%$ & $100.0 \%$ \\
\hline & \multirow[t]{2}{*}{10} & Count & 0 & 23 & 14 & 19 & 56 \\
\hline & & $\%$ within Age & $.0 \%$ & $41.1 \%$ & $25.0 \%$ & $33.9 \%$ & $100.0 \%$ \\
\hline & \multirow[t]{2}{*}{11} & Count & 1 & 25 & 9 & 3 & 38 \\
\hline & & $\%$ within Age & $2.6 \%$ & $65.8 \%$ & $23.7 \%$ & $7.9 \%$ & $100.0 \%$ \\
\hline & \multirow[t]{2}{*}{12} & Count & 4 & 49 & 13 & 16 & 82 \\
\hline & & $\%$ within Age & $4.9 \%$ & $59.8 \%$ & $15.9 \%$ & $19.5 \%$ & $100.0 \%$ \\
\hline & \multirow[t]{2}{*}{13} & Count & 1 & 52 & 25 & 10 & 88 \\
\hline & & $\%$ within Age & $1.1 \%$ & $59.1 \%$ & $28.4 \%$ & $11.4 \%$ & $100.0 \%$ \\
\hline & \multirow[t]{2}{*}{14} & Count & 0 & 29 & 8 & 5 & 42 \\
\hline & & $\%$ within Age & $.0 \%$ & $69.0 \%$ & $19.0 \%$ & $11.9 \%$ & $100.0 \%$ \\
\hline & \multirow[t]{2}{*}{15} & Count & 2 & 89 & 10 & 4 & 105 \\
\hline & & $\%$ within Age & $1.9 \%$ & $84.8 \%$ & $9.5 \%$ & $3.8 \%$ & $100.0 \%$ \\
\hline & \multirow[t]{2}{*}{16} & Count & 0 & 106 & 5 & 0 & 111 \\
\hline & & $\%$ within Age & $.0 \%$ & $95.5 \%$ & $4.5 \%$ & $.0 \%$ & $100.0 \%$ \\
\hline & \multirow[t]{2}{*}{17} & Count & 0 & 65 & 13 & 5 & 83 \\
\hline & & $\%$ within Age & $.0 \%$ & $78.3 \%$ & $15.7 \%$ & $6.0 \%$ & $100.0 \%$ \\
\hline & \multirow[t]{2}{*}{18} & Count & 0 & 38 & 4 & 2 & 44 \\
\hline & & $\%$ within Age & $.0 \%$ & $86.4 \%$ & $9.1 \%$ & $4.5 \%$ & $100.0 \%$ \\
\hline \multirow{2}{*}{\multicolumn{2}{|c|}{ Total }} & Count & 38 & 728 & 121 & 103 & 990 \\
\hline & & $\%$ within Age & $3.8 \%$ & $73.5 \%$ & $12.2 \%$ & $10.4 \%$ & $100.0 \%$ \\
\hline
\end{tabular}

Maximum proportion of obese population belongs to 10 aged Boys and minimum in 16year.

\section{Strength of Association}

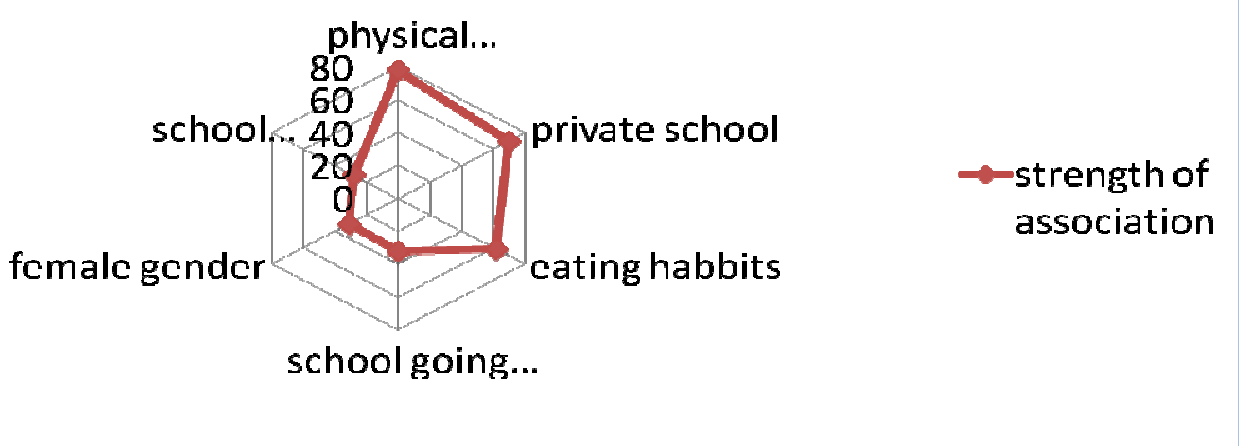

Figure: showing strength of association of different modifiable factors with obesity. 
This is a spider graph representing strength of association. Factor which is farthest from centre has greatest strength of association. In this study physical inactivity is the modifiable factor which has maximum strength of association with prevalence of obesity and overweight.

\section{Discussion}

In 2005, WHO there are concerns that increasing levels of sedentary behavior in children and adolescence are reducing energy expenditure while energy intake remains unaltered resulting in a rising prevalence of overweight and obesity [1]. Study done by Mandani S et al in Raipur city in 2012, found that out of 1114 students from single school, $20.1 \%$ of boys are overweight and $13.4 \%$ are obese and $15.6 \%$ girls are overweight and $7.6 \%$ are obese whereas M. Mehta et al[9] in his study show significant prevalence of obesity in affluent school girls in Delhi and more than half of them have central obesity.

Khader et al., (2008) study in Jordan [7], show that the daily pocket money is associated with overweight, while family monthly income is associated with obesity. Study done by Mo-Suwan et al.[19], (2000) in Thailand indicate that boys and girls in the high income families have higher mean BMI level. Kruger et al[20]., (2005) found that overweight children are the least active, mainly because of watching TV all the time. In study by Thompson et al[21]., (2004) report that the frequency of eating quick food is positively associated with BMI zscore in their longitudinal study among girls at Massachusetts Institute of Technology. In 2004 a similar study done in Hyderabad showed that the prevalence of overweight was $7.2 \%$ among the 12 to 17 year age group [8]. A study in Delhi (2007) on affluent school children showed the prevalence of obesity to be $7.4 \%$ [9]. Another study among affluent girls in Delhi (2007) reported the prevalence of obesity and overweight to be 5.3 and $15.2 \%$, respectively [10].

Obesity, overweight and central obesity and sedentary behavior coexist with undernutrition, and have become a public health problem in all the five cities of India [22]. The prevalence of obesity and sedentary behavior was significantly greater in Trivandrum, Calcutta and Bombay compared to Moradabad and Nagpur. Sedentary behavior was significantly associated with obesity compared to non-obese subjects in both sexes, which may be due to greater economic development in metro cities [11]. In 1985, Dietz et al. demonstrated that the prevalence of obesity increased by $2 \%$ for each additional hour of television viewed [12]. In 2006, WHO found that prevalence of Obesity increased by
$2 \%$ in 12-17 years old for each additional hour of television viewed. Obesity incidence increases in children who viewed more than 4 hours per day [13]. In 2013, Nora El-Said Badawi et al found a relatively high prevalence of overweight and obesity among children aged 6-12 years in Port Said city who are fond of candy and chocolates and have less consumption of fresh fruits and vegetables. They also found a relatively high prevalence of overweight and obesity among children aged 6-12 years in Port Said city who had more liking towards carbonated beverages and sugary juice consumption [14]. In 2013, Wendt et al showed that (Too) short sleep duration is one of many risk factors for overweight and obesity. It showed sufficient sleep should be there for proper health of children, sleep should neither be too less nor too more [15]. In 2001, Ludwig et al. who found that for each consumed additional serving of sugar sweetened drinks BMI and obesity increased after adjustment for anthropometric, demographic, dietary and life style variable. On other hand, eating quick meals did not significantly correlate with BMI [16].

In 2000, JJ Reilly et al Due to small school playgrounds and unsafe roads, children are discouraged from walking or cycling to school. Motorized vehicles are popular and they are perceived to be quicker and safer means of transport [17].

Incorporating $\mathrm{WC}$ as a routine measure in standard pediatric care is faced with several challenges to validity and reliability. An expert committee of the American Medical Association and the Centers for Disease Control and Prevention Task Force on Assessment, Prevention, and Treatment of Childhood Obesity was unable to recommend the routine clinical use of waist circumference for children because of incomplete information and the lack of specific guidance for its clinical application. BMI can provide a general description of adiposity characteristics in a healthy pediatric population, but it is less accurate in predicting fatness in an individual child [18]. Although BMI and abdominal adiposity measures may be highly correlated, it is desirable to obtain a BMI, where possible, and consider the utility of joint use of the two indicators. 


\section{Conclusion}

Healthy society is a wealthy society and children are the important components of the society. Prevalence of obesity is rising in school going children in Raipur city and prevalence is more so in Girls. Some of the reforms are immediately required to combat or in fact control this situation. The government, health planner, administrator and individual parent are the equal partners in delivering this message and fulfilling the agenda for the society based on our study and experience, we recommend few points for better health of the children as well as their parents.

There is diversity of religion, customs, food habits, ethnicity and geographical factors in this vast country, so we recommend a large study covering all the parts and strata, which could act as ready reference like CDC, Atlanta. This data pool is very much necessary, as it well provide guidelines to pediatricians and policy makers regarding childhood nutrition.

\section{Limitations}

- It is self reported questionnaire. Study would be more accountable if parents were also interviewed.

- Body mass index fails to distinguish between fat and fat free mass. (muscle and bone).

- Larger sample size would predict the values more precisely. i.e with less $\%$ errors.

\section{Funding: Nil, Conflict of interest: None}

\section{Permission of IRB: Yes}

\section{References}

1. Sharma A, Sharma K, Mathur KP. Growth pattern and prevalence of obesity in affluent schoolchildren of Delhi. Public Health Nutr. 2007 May;10(5):485-91.

2. Rao S, Kanade A, Kelkar R. Blood pressure among overweight adolescents from urban school children in Pune, India. Eur J Clin Nutr. 2007 May;61(5):633-41. Epub 2006 Nov 29.

3. Donohoue PA. Obesity, In: Behrman RE, Kleigman RM, Jeson HB, editors. Nelson textbook of pediatrics. $17^{\text {th }}$ ed. Philadelphia: WB Saunders; 2004. Pp. 173-7.

4. Kosti RI, Panagiotakos DB. The epidemic of obesity in children and adolescents in the world. Cent Eur J Public Health. 2006 Dec;14(4):151-9.
5. Preventing chronic disease: A vital investment. World Global Report. Geneva: World Health Organization; 2005. World Health Organization.

6. Wang G, Dietz WH. Economic burden of obesity in youths aged 6 to 17 years: 1979-1999. Pediatrics. 2002 May; 109(5):E81-1.

7. Khader Y, Irshaidat O, Khasawneh M, Amarin Z, Alomari M, Batieha A. Overweight and Obesity Among School Children in Jordan: Prevalence and Associated Factors. Matern Child Health Journal 2008; doi 10.1007/s10995-800-0362-0. 60.

8. Ramachandran A, Snehalatha C, Vinitha R, Thayyil M, Kumar CK, Sheeba L, Joseph S, Vijay V. Prevalence of overweight in urban Indian adolescent school children. Diabetes Res Clin Pract. 2002 Sep; 57 (3) : 185-90.

9. Mehta M, Bhasin SK, Agrawal K, Dwivedi S. Obesity amongst affluent adolescent girls. Indian J Pediatr. 2007 Jul;74(7):619-22.

10. Kaneria Y, Singh P, Sharma DC. Prevalence of overweight and obesity in relation to socio economic conditions in two different groups of school age children of Udaipur city (Rajastan). J Indian Assoc Community Med 2006;7:133-5.

11. Kasmini K. Prevalence of overweight and obesity among school children aged between 7-16 years amongst the 3 major ethnic groups in Kuala Lampur, Malaysia. Asia Pac J Clin Nutr 1997;6: $172-4$.

12. Dietz WH Jr, Gortmaker SL, Pediatrics. 1985 May; 75(5):807-12.

13. WHO / HBSC forum 2006, addressing the socioeconomic determinant of healthy eating habits and physical activity levels among adolescents: pp14-25.

14. Nora El-Said Badawi, Abeer Abo Barakat, Seham Awad El Sherbini, Haitham Mohamed Fawzy, Prevalence of overweight and obesity in primary school children in Port Said city, Egyptian 
Pediatric Association Gazette, Volume 61, Issue 1, January 2013, Pages 31-36.

15. Wendt EM, Pernerstorfer E, Möseneder J, Karner G (2013) Association between sleep duration and body-mass-index in 10- to 14- year-old Austrians. Ernaehrungs Umschau international 60 (8): 140-144

16. Ludwig DS, Peterson KE, Gortmaker SL. Relation between consumption of sugar-sweetened drinks and childhood obesity: A prospective, observational analysis. Lancet.2001; 357 :505 -508.

17. Whitaker RC, Wright JA, Pepe MS, Seidel KD, Dietz WH. Predicting obesity in young adulthood from childhood and parental obesity.N Engl J Med. 1997 Sep 25;337(13):869-73.

18. van der Kooy K, Leenen R, Seidell JC, Deurenberg $\mathrm{P}$, Droop A, Bakker CJ. Waist-hip ratio is a poor predictor of changes in visceral fat. Am J Clin Nutr. 1993 Mar;57(3):327-33.
19. Mo-suwan L, Tongkumchum P, Puetpaiboon. Deterterminants of overweight tracking from childhood to adolescence: a $5 y$ follow-up study of Hat Yai schoolchildren. International Journal of Obesity, 2000; 24 (12):1642-1647

20. Kruger R, Kruger HS, Maclntyre UE. The determinants of overweight and obesity among 10-to15 -year-old school children in the north west province, south Africa-the THUSAANA (transition 66 and health during urbanization of south Africans; BANAchildren) study, Public Health Nutrition, 2005; 9(3):351-358 44. Boyce $\mathrm{T}$. The media and obesity. Obesity Reviews. 2007; 8 (s1): 201-205.

21. Thompson OM, Ballew C, Resnicow K, Must A, Bandini LG, Dietz WH. Food purchased away from home as a predictor of change in BMI z-score among girls. International Journal of obesity and Related Metabolic Disorder, 2004; 28(2):282-9.

22. Kasmini K. Prevalence of overweight and obesity among school children aged between 7-16 years amongst the 3 major ethnic groups in Kuala Lampur, Malaysia. Asia Pac J Clin Nutr 1997;6:172-4.

\section{How to cite this article?}

Gandhi A, Phuljhele S, Rao B.N. Prevalence of obesity among school children aged 6-18 years with special reference to differences in government and private schools. Int J Med Res Rev 2017;5(05):524-530. doi:10.17511/ijmrr. 2017.i05.14. 